\title{
СКРЫЛЕВ Л.Д.
}

(5.01.1935-1.02.1999)

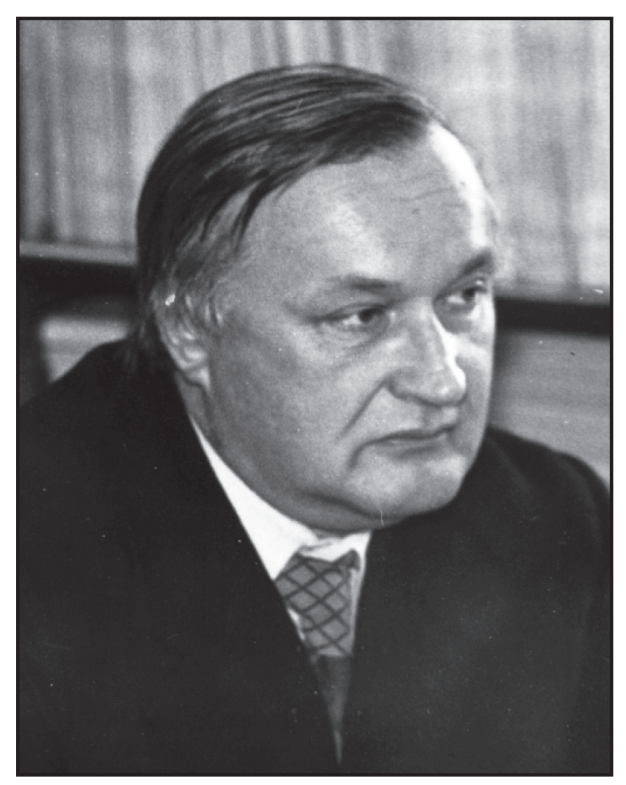

Пятого января 2015 года исполнилось 80 лет со дня рождения Скрылева Льва Дмитриевича - доктора химических наук, профессора, заслуженного деятеля науки и техники Украины, заведующего кафедрой физической и коллоидной химии ОГУ им. И.И. Мечникова в 1972-1999 гг.

Лев Дмитриевич родился на Урале, в г. Свердловске (ныне Екатеринбург) в семье инженера-механика и преподавателя русского языка и литературы. В 1958 г. окончил физико-технический факультет Уральского политехнического института по специальности «Технология редких металлов» и в том же году поступил в аспирантуру. По окончании аспирантуры, в 1961 г. защитил кандидатскую диссертацию на тему «Пенное фракционирование коллоидно-растворенных смешанных ферроцианидов тяжелых металлов», посвященную поиску путей решения важнейшей экологической проблемы - обезвреживанию жидких радиоактивных отходов. Над диссертацией работал под руководством профессора С.Г. Мокрушина - сподвижника академика П.А. Ребиндера и профессора С.А. Вознесенского - ученика выдающегося немецкого физикохимика Г. Фрейндлиха.

В 1961-1963 гг. Скрылев Л.Д работал ассистентом Уральского политехнического института, в 1963-1966 - старшим научным сотрудником Уральского НИХИ, в 1966-1968 гг. - доцентом кафедры физической химии Уральского лесотехнического института, а в 1968-1971 гг. - зав. кафедрой общей и неорганической химии этого же института.

В 1968 г. Л.Д. Скрылев защитил докторскую диссертацию на тему «Физикохимические основы адсорбционных методов выделения коллоидов». Итогом работы над диссертацией явилась разработка физико-химических основ флотационного, эмульсионного и суспензионного методов выделения коллоиднорастворенных веществ. Диссертация внесла заметный вклад в решение проблемы защиты окружающей среды. В 1969 г. Л.Д. Скрылев получил ученое звание професcopa.

С 1971 г. научная, педагогическая и общественная деятельность Льва Дмитриевича была связана с Одесским государственным университетом им. И.И. Мечникова. Читал общие курсы лекций по неорганической, физической и коллоидной химии, спецкурс «Основы научных исследований». Написал для студентов учебные пособия: «Химическая термодинамика», «Химическая кинетика и катализ», «Физические процессы в водных растворах», «Электрохимические процессы в водных растворах электролитов». 
Л.Д. Скрылева отличала широта научных взглядов. Хорошо владея аппаратом физической химии, он успешно работал в различных областях химии и химической технологии. Однако в основном научная деятельность профессора Л.Д. Скрылева была связана с физико-химией поверхностных явлений, проблемами экологии и рационального использования природных ресурсов.

Л.Д. Скрылев - известный у нас в стране и за рубежом специалист в области коллоидной химии и флотационной очистки сточных вод промышленных предприятий, автор более шестидесяти изобретений и более четырехсот статей, опубликованных в ведущих журналах стран СНГ. Л.Д. Скрылевим с соавторами была впервые в мире (Alch. Chem. Eng. Research and Development, 1972, v.18, № 5, p.1024) предложена идея концентрирования разбавленных водных растворов методами флотации с носителем и осадительной флотации.

Талантливый ученый, внимательный и строгий педагог, профессор Л.Д. Скрылев много внимания уделял подготовке научных кадров. Под его руководством подготовлено 4 доктора и 25 кандидатов наук. Он был членом трех Специализированных Советов по защите кандидатских и докторских диссертаций. В течение 5 лет был председателем одного из таких Советов. Высокий научный авторитет профессора Л.Д. Скрылева позволил ему на протяжении многих лет быть референтом РЖХим, членом оргкомитетов и председателем секций многих Всесоюзных и Украинских научных конференций и симпозиумов, редактором научных сборников, председателем Одесского областного правления ВХО им. Д.И. Менделеева.

Л.Д. Скрылевым и его учениками выполнен большой объем фундаментальных исследований, направленных на изучение количественных закономерностей ионной флотации. В ходе этих исследований, которые с полным основанием можно считать классическими, были отработаны типовые технологии флотационной очистки сточных вод, загрязненных наиболее экологически опасными веществами. Под его руководством кафедра физической и коллоидной химии ОГУ им. И.И. Мечникова превратилась в активно функционирующий научно-исследовательский центр. Наиболее крупным достижением кафедры явилась разработка технической документации и создание ряда участков флотационной очистки сточных вод гальванических производств (ПО «Черновцылегмаш», Одесский завод «Эпсилон», Хмельницкий НПО «Катион» и др.). Технологические схемы и их аппаратурное оформление были отмечены золотой медалью ВДНХ СССР и тремя серебряными медалями ВДНХ УССР.

Одним из важнейших результатов научной и организационной деятельности Л.Д. Скрылева стали создание научного коллектива, становление научной школы «Теоретические основы флотационной очистки техногенных вод». Не каждому учёному суждено оставить после себя школу. Не формальную школу учеников, защитивших диссертации под покровительством мэтра, а школу учёных, продолжающих начатое Учителем дело. В настоящее время деятельность научной школы направлена на развитие нового научного направления в теории и практике ионной флотации - разработке коллоидно-химических основ эффективных способов выделения ценных и токсичных компонентов растворов, объединяющих элементы флотации (основной процесс), экстракции, сорбции, коагуляции, флокуляции.

Высочайший профессионализм, полная самоотдача в работе, требовательность и доброжелательность, широта кругозора - эти и многие другие профессиональные и человеческие качества привлекали к Льву Дмитриевичу учеников, коллег и друзей. Для нас Лев Дмитриевич остался прежде всего человеком, открывшим нам 
путь в науку. Только теперь, по прошествии многих лет после его ухода, мы понимаем, как много дало нам общение с этим неординарным человеком. Ученики помнят своего учителя. Учитель жив в своих учениках, продолжающих его дела и идеи. «Талантливый человек талантлив во всем» - эта истина подтверждается примером жизни Л.Д. Скрылева.

Светлая память об Ученом и Учителе навсегда сохранится в наших сердцах.

Тот, кто жил для вещей, всё теряет с последним дыханьем,

Тот, кто жил для людей, после смерти живёт средь живых.

Коллектив кафедры физической и коллоидной химии Одесского национального университета имени И.И. Мечникова 